\title{
Heart injurysigns are associated with higher and earlier mortality in coronavirus disease 2019 (COVID-19)
}

Chaomin $\mathrm{Wu}^{1,2^{*}}$, Xianglin $\mathrm{Hu}^{2^{*}}$, Jianxin Song ${ }^{3^{*}}$, Chunling $\mathrm{Du}^{1^{*}}$, Jie $\mathrm{Xu}^{4}$, Dong Yang ${ }^{2}$, Dechang Chen ${ }^{5}$, Ming Zhong ${ }^{6}$, Jinjun Jiang ${ }^{2}$, Weining Xiong ${ }^{7}$, Ke Lang $^{2}$, Yuye Zhang ${ }^{2}$, Guohua Shi ${ }^{8}$, Lei $\mathrm{Xu}^{9}$, Yuanlin Song ${ }^{1,2,10,11 \dagger}$, Xin Zhou ${ }^{12 \dagger}$, Ming Wei ${ }^{13 \dagger}$, Junhua Zheng $^{13,14 \dagger}$.; The first batch of medical teams from Shanghai to support Hubei, China and study group.

1. Department of Pulmonary Medicine, QingPu Branch of Zhongshan Hospital Affiliated to Fudan University, Shanghai 201700, China.

2. Department of Pulmonary Medicine, Zhongshan Hospital, Fudan University, Shanghai 200032, China.

3. Department of Infectious Diseases, Tongji Hospital, Tongji Medical College, Huazhong University of Science and Technology, 430030, Wuhan, China.

4. Department of Infectious Diseases, Fengxian Guhua Hospital, Shanghai, China.

5. Department of Critical Care Medicine, Ruijin Hospital, Shanghai Jiao Tong University School of Medicine, Shanghai 200025, China.

6. Department of Critical Care Medicine, Zhongshan Hospital, Fudan University, Shanghai 200032, China.

7. Department of Respiratory Medicine, Shanghai Ninth People's Hospital, Shanghai Jiaotong University School of Medicine, Shanghai, China.

8. Department of Pulmonary Medicine, Qingpu Traditional Chinese Medicine Hospital, Shanghai, China.

9. Department of Emergency Medicine, Gongli Hospital, Pudong New Area, Shanghai, China.

10. Shanghai Respiratory Research Institute, Shanghai 200032, China.

11. National Clinical Research Center for Aging and Medicine, Huashan Hospital, Fudan University, Shanghai, China. 
12. Department of Pulmonary Medicine, Shanghai General Hospital, School of Medicine in Shanghai Jiao Tong University, Shanghai, 200080, China.

13. Tuberculosis and Respiratory Department, Wuhan Jinyintan Hospital, Wuhan 430023, China.

14. Department of Urology, Shanghai General Hospital, School of Medicine in Shanghai Jiao Tong University, Shanghai, 200080, China.

* Chaomin Wu, Xianglin Hu, Jianxin Song and Chunling Du contributed equally to this work.

\section{$\dagger$ Corresponding author:}

Yuanlin Song, Department of Pulmonary Medicine, Zhongshan Hospital, Fudan University, Shanghai 200032, China. E-mail: ylsong70@163.com

Xin Zhou, Department of Pulmonary Medicine, Shanghai General Hospital, School of Medicine in Shanghai Jiao Tong University, Shanghai, 200080, China. E-mail: xzhou53@163.com

Ming Wei, Tuberculosis and Respiratory Department, Wuhan Jinyintan Hospital, Wuhan 430023, China.1508257434@qq.com

Junhua Zheng, Department of Urology, Shanghai General Hospital, School of Medicine in Shanghai Jiao Tong University, Shanghai, 200080, China. E-mail: zhengjh0471@sina.com

\section{Conflicts of Interest: All authors declared that they have no Conflicts of Interest}




\section{Key points}

\section{Question}

Does coronavirus disease 2019 (COVID-19) cause heart injury and hereby impact mortality?

\section{Findings}

In this retrospective cohort study including 188 patients with COVID-19, patients with high levels of high-sensitivity cardiac troponin I (hs-TNI) on admission had significantly higher mortality $(50.0 \%)$ than patients with moderate or low levels of hs-TNI (10.0\% or $9.1 \%)$ hs-TNI level on admission was significantly negatively correlated with survival days $(r=-0.42,95 \% \mathrm{Cl}=-0.64 \sim-0.12, \mathrm{P}=0.005)$.

\section{Meaning}

COVID-19 patients with signs of heart injury on admission must be early identified and carefully managed by cardiologists, in order to maximally prevent or rescue heart injury-related mortality in COVID-19. 


\section{Abstract}

\section{Importance}

Heart injury can be easily induced by viral infection such as adenovirus and enterovirus. However, whether coronavirus disease 2019 (COVID-19) causes heart injury and hereby impacts mortality has not yet been fully evaluated.

\section{Objective}

To explore whether heart injury occurs in COVID-19 on admission and hereby aggravates mortality later.

\section{Design, Setting, and Participants}

A single-center retrospective cohort study including 188 COVID-19 patients admitted from December 25, 2019 to January 27, 2020 in Wuhan Jinyintan Hospital, China; follow up was completed on February 11, 2020.

\section{Exposures}

High levels of heart injury indicators on admission (hs-TNI; CK; CK-MB; LDH; $\alpha-\mathrm{HBDH})$.

\section{Main Outcomes and Measures}

Mortality in hospital and days from admission to mortality (survival days).

\section{Results}

Of 188 patients with COVID-19, the mean age was 51.9 years (standard deviation: 14.26; range: 21 83 years) and 119 (63.3\%) were male. Increased hs-Tnl levels on admission tended to occur in older patients and patients with comorbidity (especially hypertension). High hs-Tnl on admission ( $\geq 6.126 \mathrm{pg} / \mathrm{mL}$ ), even within the clinical 
normal range $(0 \sim 28 \mathrm{pg} / \mathrm{mL})$, already can be associated with higher mortality. High hs-Tnl was associated with increased inflammatory levels (neutrophils, IL-6, CRP, and PCT) and decreased immune levels (lymphocytes, monocytes, and $C D 4^{+}$and $C D 8^{+} \mathrm{T}$ cells). CK was not associated with mortality. Increased CK-MB levels tended to occur in male patients and patients with current smoking. High CK-MB on admission was associated with higher mortality. High CK-MB was associated with increased inflammatory levels and decreased lymphocytes. Increased LDH and $\alpha$-HBDH levels tended to occur in older patients and patients with hypertension. Both high LDH and $\alpha-\mathrm{HBDH}$ on admission were associated with higher mortality. Both high LDH and $\alpha-\mathrm{HBDH}$ were associated with increased inflammatory levels and decreased immune levels. hs-TNI level on admission was negatively correlated with survival days ( $r=$ $-0.42,95 \% \mathrm{Cl}=-0.64 \sim-0.12, \mathrm{P}=0.005)$. LDH level on admission was negatively correlated with survival days $(r=-0.35,95 \% \mathrm{Cl}=-0.59 \sim-0.05, \mathrm{P}=0.022)$.

\section{Conclusions and Relevance}

Heart injury signs arise in COVID-19, especially in older patients, patients with hypertension and male patients with current smoking. COVID-19 virus might attack heart via inducing inflammatory storm. High levels of heart injury indicators on admission are associated with higher mortality and shorter survival days. COVID-19 patients with signs of heart injury on admission must be early identified and carefully managed by cardiologists, because COVID-19 is never just confined to respiratory injury. 


\section{Introduction}

Viral infection is a common cause of heart injury such as myocarditis. It is well known that adenovirus, enterovirus and herpesvirus are the most common infectious etiologies for heart injury [1]. Since coronavirus-related carditis was first reported in 1980 [2], increasing studies noted that coronavirus is an uncommon but unneglectable pathogen for heart injury. For instance, we found the coronavirus of Severe Acute Respiratory Syndrome Coronavirus (SARS-CoV) in 2003 in China had no obvious connections with heart injury. However, it was reported that the coronavirus of Middle East Respiratory Syndrome (MERS-CoV) in 2012 in Saudi Arabia could cause acute myocarditis and heart failure [3].

Coronavirus disease 2019 (COVID-19) is a novel infectious viral pneumonia breaking out in Wuhan, China since Dec, 2019 [4, 5]. By Feb 20, 2020 in China, 75,465 patients were diagnosed with COVID-19 and 2,236 patients deceased [6]. Based on our recent experts clinical experience on COVID-19, we found severe COVID-19 patients are difficult to rescue not only because respiratory failure but also susceptibility to heart failure. The coronavirus for COVID-19 is a new strain which was not previously identified. Whether the coronavirus for COVID-19 causes heart injury and thereby impacts mortality has not been fully evaluated. Therefore, in this retrospective cohort study, we fully assessed heart injury indicators on admission in COVID-19 patients. We aimed to explore whether heart injury already occurs in COVID-19 at early stage and hereby aggravates mortality later. 


\section{Methods}

\section{Study population}

From Dec 25, 2019 to Jan 27, 2020, 188 COVID-19 patients admitted to Wuhan Jinyintan Hospital (Hubei, China) were selected. All enrolled patients were definitely diagnosed with COVID-19 pneumonia according to the previously reported criteria [7]. Patients with missing clinical information were excluded. Age of the enrolled patients ranged from 21 to 83 years old. Up to Feb 11, 2020, follow up in hospital was completed for all patients. One hundred and forty-five patients were cured and discharged while 43 patients deceased in hospital. This research was approved by the Review Board of Wuhan Jinyintan Hospital. Written informed consent was waived because this research was retrospective observation and deindividuation.

\section{Data collection}

Data were retrieved from electronic medical records. Demographic and clinical parameters included age, gender, history of Huanan seafood market exposure, history of family infection, smoking status, comorbidity, initial symptoms and signs, vital signs on admission, complications on admission and drug treatment regimen. Primary outcome was mortality in hospital. Days from admission to death (survival days) were also calculated for deceased patients. Whether transfer to intensive care unit (ICU) was recorded as a secondary outcome.

Heart injury indicators measured on admission were collected, including high-sensitivity cardiac troponin I (hs-TNI), creatine kinase (CK), creatine kinase-MB (CK-MB), lactic dehydrogenase (LDH) and $\alpha$-hydroxybutyrate dehydrogenase 
$(\alpha-H B D H)$. The clinical normal range of hs-TNI was $0 \sim 28 \mathrm{pg} / \mathrm{mL}$. The clinical normal range of $\mathrm{CK}$ was 50 310 U/L. The clinical normal range of CK-MB was 0 24 U/L. The clinical normal range of LDH was $120 \sim 250 \mathrm{U} / \mathrm{L}$. The clinical normal range of $\alpha-\mathrm{HBDH}$ was 72 182 U/L. All Heart injury indicators were divided into three levels (low, moderate or high level) based on the cutoff values of $33^{\text {th }}$ and $67^{\text {th }}$ percentile.

Inflammatory levels indicators were collected, including white blood cells (WBC), neutrophils, interleukin-6 (IL-6), C-reaction protein (CRP), procalcitonin (PCT) and erythrocyte sedimentation rate (ESR). Immune levels indicators were collected, including lymphocytes, monocytes, $\mathrm{T}$ cells count, and $\mathrm{CD} 4^{+}$and $\mathrm{CD} 8^{+} \mathrm{T}$ cells count.

\section{Statistical analysis}

SPSS for Windows (Version 24.0, IBM) and Graphpad prism 7.0 software were used for statistical analysis. Continuous parameters were displayed by mean \pm standard deviation (SD) or median with quartiles. Categorical parameters were displayed by percentage with number. One way ANOVA or Kruskal-Wallis test was performed for multiple comparisons of continuous data. Tukey's multiple comparisons test or Dunn's multiple comparisons test was used for adjusted $\mathrm{P}$ value. Chi-square test was performed for categorical data and Bonferroni method was used for adjusted $\mathrm{P}$ value. Spearman correlation was performed. Coefficient of $r$ with $95 \%$ confidence interval $(\mathrm{Cl})$ was used to measure the correlation magnitude. $\mathrm{P}<0.05$ was considered statistically significant. 


\section{Results}

The baseline clinical and laboratory characteristics were presented in Table 1. Patients' mean age was $51.9 \pm 14.26$ years old. Male accounted for $63.3 \%$ of the population. Huanan seafood market exposure accounted for $48.9 \%$ while infection by family members accounted for $8.0 \%$ of the population. There were $9.0 \%$ patients with current smoking. Hypertension (20.2\%) and diabetes (10.6\%) ranked as the most common comorbidities. Fever $(92.6 \%)$ and cough $(83.5 \%)$ were the most common initial symptoms and signs. Approximately $11.2 \%$ patients had hs-TNI exceeding clinical upper normal limit on admission. Approximately $68.6 \%$ patients had LDH exceeding clinical upper normal limit on admission. Approximately $76.1 \%$ patients had $\alpha-\mathrm{HBDH}$ exceeding clinical upper normal limit on admission. Approximately $11.2 \%$ patients had CK exceeding clinical upper normal limit on admission. Approximately $10.1 \%$ patients had CK-MB exceeding clinical upper normal limit on admission. Antibiotics (98.4\%) and non-specific antiviral drugs (84.0\%) were used in most patients. There were $50(26.6 \%)$ patients transferring to ICU. There were $43(22.9 \%)$ patients deceasing in hospital. The median survival days for deceased patients were 7 (4-11) days.

As shown in Table 2, increased hs-Tnl levels were more likely to occur in older patients and patients with hypertension or diabetes. High hs-Tnl was independent of acute respiratory symptoms and respiratory failure $(P>0.05)$. High hs-Tnl on admission ( $\geq 6.126 \mathrm{pg} / \mathrm{mL}$ ), even within the clinical normal range (0 28 pg/mL), already can be associated with higher mortality (50.0\%). High hs-Tnl was significantly 
associated with increased inflammatory levels (neutrophils, IL-6, CRP, and PCT) and decreased immune levels (lymphocytes, monocytes, and $\mathrm{CD} 4^{+}$and $\mathrm{CD} 8^{+} \mathrm{T}$ cells). Survival days were obviously shorter for deceased patients with high hs-TNI (median: 7 days) when compared to patients with low and moderate hs-TNI (median: 11 and 8.5 days, respectively), although it was hard to reach statistical significance because the deceased cases in the three groups were extremely uneven distribution.

As shown in Table 3, increased CK-MB levels were more likely to occur in male patients and patients with current smoking. High CK-MB on admission ( $\geq 18 \mathrm{U} / \mathrm{L}$ ) was associated with higher mortality (34.9\%). High CK-MB was significantly associated with increased inflammatory levels (WBC, neutrophils, CRP and PCT) and decreased lymphocytes levels. High CK-MB was independent of acute respiratory symptoms and respiratory failure $(P>0.05)$. CK was not associated with mortality (Supplementary table 1).

As shown in Table 4, increased LDH levels were more likely to occur in older patients and patients with hypertension. High LDH was significantly associated with acute respiratory symptoms and respiratory failure $(P<0.05)$. High LDH on admission ( $\geq 354.5 \mathrm{U} / \mathrm{L}$ ) was associated with higher mortality (53.2\%). High LDH was significantly associated with increased inflammatory levels (WBC, neutrophils, IL-6, CRP, PCT and ESR) and decreased immune levels (lymphocytes, monocytes, T cells and $\mathrm{CD} 4^{+} \mathrm{T}$ cells). Survival days were obviously shorter for deceased patients with high LDH (median: 7 days) when compared to patients with low and moderate LDH 
(median: 11 days, both), although it was hard to reach statistical significance because the deceased cases in the three groups were extremely uneven distribution.

As shown in Table 5, increased $\alpha$-HBDH levels were more likely to occur in older patients and patients with hypertension. High $\alpha-\mathrm{HBDH}$ was significantly associated with acute respiratory symptoms and respiratory failure $(P<0.05)$. High $\alpha-\mathrm{HBDH}$ on admission ( $\geq 305 \mathrm{U} / \mathrm{L}$ ) was associated with higher mortality (53.4\%). High $\alpha-\mathrm{HBDH}$ was significantly associated with increased inflammatory levels (WBC, neutrophils, IL-6, CRP and PCT) and decreased immune levels (lymphocytes, monocytes, T cells and $\mathrm{CD} 4^{+} \mathrm{T}$ cells).

As shown in Figure 1, the higher hs-TNI on admission was, the shorter survival days would be. hs-TNI level on admission was significantly negatively correlated with survival days $(r=-0.42,95 \% \mathrm{Cl}=-0.64 \sim-0.12, \mathrm{P}=0.005)$. The higher $\mathrm{LDH}$ on admission was, the shorter survival days would be. LDH level on admission was significantly negatively correlated with survival days $(r=-0.35,95 \% \mathrm{Cl}=-0.59 \sim-0.05, \mathrm{P}=0.022)$. CK-MB and $\alpha-\mathrm{HBDH}$ were not significantly correlated with survival days (both $\mathrm{P}>$ $0.05)$

\section{Discussion}

In this study, we first assessed the associations between heart injury indicators and mortality in COVID-19 patients. hs-TNI is a biomarker released into blood once myocardial necrosis. Aberrant hs-TNI usually specifically indicates acute myocardial infarction [8]. In our study, we found hs-TNI increase tended to occur in older 
patients and patients with comorbidities (especially hypertension). Approximately 11.2\% COVID-19 patients happened to acute myocardial infarction on admission (aberrant hs-TNI $>28 \mathrm{pg} / \mathrm{mL}$ ), which was consistent to the previous reports $[9,10]$. More importantly, we found high hs-Tnl on admission ( $\geq 6.126 \mathrm{pg} / \mathrm{mL}$ ), even within the clinical upper normal limit ( $\leq 28 \mathrm{pg} / \mathrm{mL}$ ), already can be associated with higher mortality. hs-TNI level was significantly negatively correlated with survival days. Therefore, we suggest the clinical upper normal limit of hs-TNI should be lowered for COVID-19, in order to avoid negligence of heart injury for COVID-19 patients on admission. Our suggestion also agrees with the opinion, which was issued on The Lancet in 2018 [11], that reclassification of hs-TNI for acute coronary syndrome in emergency departments in order to improve clinical outcomes.

CK-MB is another sensitive heart injury indicator which can also reflect myocarditis and myocardial infarction. After acute myocardial infarction, CK-MB will begin to increase at 2-4 hours, peak at 12 hours, and return to baseline within 48-72 hours $[12,13]$. In our study, we found CK-MB increase tended to occur in male patients and patients with current smoking. Approximately $10.1 \%$ COVID-19 patients had CK-MB exceeding clinical upper normal limit (24 U/L) on admission. High CK-MB on admission ( $\geq 18 \mathrm{U} / \mathrm{L}$ ), even within the clinical upper normal limit $(\leq 24 \mathrm{U} / \mathrm{L}$ ), already was associated higher mortality. These results proved heart injury such as viral myocarditis or myocardial infarction indeed occurred in COVID-19 on admission and predicted adverse clinical outcomes. 
LDH and $\alpha-H B D H$ are two kinds of myocardial enzymes. LDH and $\alpha-H B D H$ mainly exist in myocardia and would be released into blood once myocardial injury. Although LDH and $\alpha-\mathrm{HBDH}$ increases are relatively less specific in heart injury, they also play important helping roles in recognition of myocarditis or myocardial infarction $[14,15]$. In our study, we found increases of $\mathrm{LDH}$ and $\alpha-\mathrm{HBDH}$ were more likely to occur in older patients and patients with hypertension. Both high LDH and $\alpha-\mathrm{HBDH}$ on admission were associated with higher mortality. In addition, we found high LDH and $\alpha$-HBDH were associated with more acute respiratory symptoms such as breathlessness, chest distress or pain, dyspnea or respiratory failure on admission. This result also implied that the increases of LDH and $\alpha-\mathrm{HBDH}$ might not be specific due to heart injury. LDH and $\alpha-\mathrm{HBDH}$ increases might not merely be induced by heart injury, but also be induced by lung or other organs injury. Nevertheless, LDH level on admission was significantly negatively correlated with survival days.

The potential mechanism for COVID-19-caused heart injury might be virus-induced inflammatory storm. Inflammatory cells infiltration and inflammatory cytokines release can directly lead to apoptosis or necrosis of myocardial cells [16, 17]. In our study, we found high levels of heart injury indicators were associated with increased levels of inflammatory cells (WBC and neutrophils) and inflammatory cytokines (IL-6 and CRP). Therefore, we speculated that COVID-19 infection would cause heart injury such as myocarditis or myocardial infarction by inducing inflammatory cells infiltration and inflammatory cytokines storm. Early and special anti-inflammatory treatments should be undertaken by cardiologists to protect 
myocardium [18]. Another potential mechanism for COVID-19-caused heart injury might be angiotensin-converting enzyme 2 (ACE2)-mediated direct injury to heart. ACE2 as a human cell receptor had a strong binding affinity to the Spike protein of 2019-nCoV, namely Severe Acute Respiratory Syndrome Coronavirus-2 (SARS-CoV-2) [19]. Recent study reported ACE2 is highly expressed in heart [20]. Therefore, SARS-CoV-2 of COVID-19 might directly attack heart by binding ACE2 on myocardial cells.

Some limitations existed in this study. First, we only assessed heart injury from the perspective of serum myocardial enzymes and protein. It would be better if echocardiography and electrocardiograph were also measured in this study. Secondly, it would be better if we could assess heart injury-specific mortality in the future study with a larger sample size. Thirdly, we have not been able to obtain myocardial tissues from COVID-19 patients. Thus we currently cannot directly observe myocardial injury from the golden standard of pathology. Although the first autopsy of COVID-19 patient was completed and pulmonary pathology was obtained on Feb 16, 2020 in Wuhan Jinyintan Hospital (China), it remains a long way to remind clinicians to focus on cardiac pathology for COVID-19 infection. Our present results also can remind pathologists to pay attention to cardiac pathology in the future, especially for those deceased COVID-19 patients who had high heart injury indicators on admission. 


\section{Conclusions}

In summary, heart injury signs arise in COVID-19 on admission and would be associated with subsequently higher and earlier mortality. COVID-19 virus might attack heart via inducing inflammatory storm or attack heart directly. Clinicians must beware of heart injury indicators for COVID-19 patients, especially for those with older age, hypertension and current smoking. In order to maximally prevent or rescue heart injury-related mortality in COVID-19, cardiologists must participate in early and special managements for patients with COVID-19.

\section{Conflicts of Interest}

All authors declared that they have no Conflicts of Interest.

All authors have seen and approved the manuscript.

\section{Data Availability}

The data used to support the findings of this study are available from the corresponding author upon appropriate request.

\section{Acknowledgements}

This study was supported by The National Natural Science Foundation of China (NSFC)

(81972393, 81772705, 31570775), NSFC (81630001, 81770075), Shanghai Municipal

Key Clinical Specialty (shslczdzk02201) and Shanghai Top-Priority Clinical Key 
Disciplines Construction Project (2017Zz02013), Sub-specialist project of Qingpu Branch of Zhongshan Hospital, Fudan university (YZK 2019-04), 2019 Hospital-level National Natural Science Foundation Incubation Project (QYP 2019-03), Science and technology development fund of Qingpu district science and technology commission in 2018 (QKY 2018-01), Academic Leader of Shanghai Qingpu District Healthcare Commission (WD2019-36), Shanghai key discipline of medicine (ZK2019B07 SZ2019-1), NSFC(81870035), Project of Shanghai municipal commission of health and family planning (201740210).

\section{Reference}

1. Pollack A, Kontorovich AR, Fuster V, Dec GW. Viral myocarditis--diagnosis, treatment options, and current controversies. Nat Rev Cardiol. 2015; 12(11):670-80.

2. Riski H, Hovi T, Frick MH. Carditis associated with coronavirus infection. Lancet. 1980;2(8185):100-1.

3. Alhogbani T. Acute myocarditis associated with novel Middle east respiratory syndrome coronavirus. Ann Saudi Med. 2016;36(1):78-80.

4. Zhu N, Zhang D, Wang W, et al. A Novel Coronavirus from Patients with Pneumonia in China, 2019. N Engl J Med. 2020. https://doi: 10.1056/NEJMoa2001017.

5. Heymann David L, Shindo Nahoko, WHO Scientific and Technical Advisory Group for Infectious Hazards. COVID-19: what is next for public health?. Lancet 2020; published 
online Feb 13. https://doi.org/10.1016/S0140-6736/20)30374-3

6. NHC of China. The latest situation of new coronavirus pneumonia up to February 20, 24:00,

2020.http://www.nhc.gov.cn/xcs/yqtb/202002/ac1e98495cb04d36b0d0a4e1e7fab545.shtml (accessed Feb 21, 2020).

7. Chen N, Zhou M, Dong X, et al. Epidemiological and clinical characteristics of 99 cases of 2019 novel coronavirus pneumonia in Wuhan, China: a descriptive study. Lancet 2020; published online Jan 29. https://doi.org/10.1016/S0140-6736(20)30211-7.

8. Neumann JT, Sörensen NA, Ojeda F, et al. Early diagnosis of acute myocardial infarction using high-sensitivity troponin I. PLoS One. 2017;12(3):e0174288

9. Huang C, Wang Y, Li X, et al. Clinical features of patients infected with 2019 novel coronavirus in Wuhan, China. Lancet 2020; published online Jan 24. https://doi.org/10.1016/S0140-6736(20)30183-5.

10. Wang D, Hu B, Hu C, et al. Clinical Characteristics of 138 Hospitalized Patients With 2019 Novel Coronavirus-Infected Pneumonia in Wuhan, China. JAMA. 2020

11. Shah ASV, Anand A, Strachan FE, et al. High-sensitivity troponin in the evaluation of patients with suspected acute coronary syndrome: a stepped-wedge, cluster-randomised controlled trial. Lancet. 2018; 392(10151):919-928.

12. Ndrepepa G, Kastrati A. Creatine kinase myocardial band - a biomarker to assess prognostically relevant periprocedural myocardial infarction. Int J Cardiol. 2018; 270:118-119.

13. Hartman MHT, Eppinga RN, Vlaar PJJ, et al. The contemporary value of peak creatine 
kinase-MB after ST-segment elevation myocardial infarction above other clinical and angiographic characteristics in predicting infarct size, left ventricular ejection fraction, and mortality. Clin Cardiol. 2017; 40(5):322-328.

14. Vasudevan G, Mercer DW, Varat MA. Lactic dehydrogenase isoenzyme determination in the diagnosis of acute myocardial infarction. Circulation. 1978; 57(6):1055-7.

15. van der Laarse A, Hermens WT, Hollaar L, et al. Assessment of myocardial damage in patients with acute myocardial infarction by serial measurement of serum alpha-hydroxybutyrate dehydrogenase levels. Am Heart J. 1984;107(2):248-60.

16. Zhang T, Zhang Y, Cui M, et al. CaMKII is a RIP3 substrate mediating ischemia- and oxidative stress-induced myocardial necroptosis. Nat Med. 2016;22(2):175-82.

17. Fung G, Luo H, Qiu Y, Yang D, McManus B. Myocarditis. Circ Res. 2016;118(3):496-514.

18. Deftereos S, Giannopoulos G, Angelidis C, et al. Anti-Inflammatory Treatment With Colchicine in Acute Myocardial Infarction: A Pilot Study. Circulation. 2015;132(15):1395-403.

19. Daniel Wrapp, Nianshuang Wang, Kizzmekia S, et al. Cryo-EM Structure of the 2019-nCoV Spike in the Prefusion Conformation. bioRxiv 2020.02.11.944462; doi: https://doi.org/10.1101/2020.02.11.944462

20. Zou Xin, Chen Ke, Zou Jiawei, et al. The single-cell RNA-seq data analysis on the receptor ACE2 expression reveals the potential risk of different human organs vulnerable to Wuhan 2019-nCoV infection. Front. Med., [Epub ahead of print] doi: 10.1007/s11684-020-0754-0.http://journal.hep.com.cn/fmd/EN/10.1007/s11684-020-07 
medRxiv preprint doi: https://doi.org/10.1101/2020.02.26.20028589; this version posted February 29, 2020. The copyright holder for this preprint (which was not certified by peer review) is the author/funder, who has granted medRxiv a license to display the preprint in perpetuity.

All rights reserved. No reuse allowed without permission. 
medRxiv preprint doi: https://doi.org/10.1101/2020.02.26.20028589; this version posted February 29, 2020. The copyright holder for this preprint (which was not certified by peer review) is the author/funder, who has granted medRxiv a license to display the preprint in perpetuity. All rights reserved. No reuse allowed without permission.

Table 1, Clinical and laboratory characteristics of the enrolled patients $(n=188)$.

\begin{tabular}{|c|c|c|}
\hline Parameters & & All patients \\
\hline \multirow[t]{2}{*}{ Age (years) } & Mean \pm SD & $51.9 \pm 14.26$ \\
\hline & Median $\left(25^{\text {th }}\right.$ and $75^{\text {th }}$ percentile $)$ & $51(43 \sim 60)$ \\
\hline \multicolumn{2}{|l|}{ Male } & $119(63.3 \%)$ \\
\hline \multicolumn{2}{|c|}{ Huanan seafood market exposure } & 92 (48.9\%) \\
\hline \multicolumn{2}{|c|}{ Infection by family members } & $15(8.0 \%)$ \\
\hline \multicolumn{2}{|l|}{ Current smoking } & $17(9.0 \%)$ \\
\hline \multicolumn{2}{|l|}{ Comorbidity $^{a}$} & $64(34.0 \%)$ \\
\hline & Hypertension & $38(20.2 \%)$ \\
\hline & Diabetes & $20(10.6 \%)$ \\
\hline \multicolumn{3}{|c|}{ Initial symptoms and signs ${ }^{b}$} \\
\hline & Fever & $174(92.6 \%)$ \\
\hline & Highest temperature $\left({ }^{\circ} \mathrm{C}\right)(\mathrm{n}=156)$ & $38.73 \pm 0.67$ \\
\hline & Cough & $157(83.5 \%)$ \\
\hline & Sputum & $74(39.4 \%)$ \\
\hline & Breathlessness & $72(38.3 \%)$ \\
\hline & Chest distress or pain & $63(33.5 \%)$ \\
\hline & Fatigue or myalgia & $61(32.5 \%)$ \\
\hline & Dyspnea & $24(12.8 \%)$ \\
\hline \multicolumn{2}{|c|}{ Days from symptoms/signs to admission } & $9(7-12)$ \\
\hline \multicolumn{3}{|c|}{ Vital signs on admission } \\
\hline & Temperature $\left({ }^{\circ} \mathrm{C}\right)$ & $36.91 \pm 0.76$ \\
\hline & Heart rate (beats/min) & $88(82 \sim 98)$ \\
\hline & Respiratory rate (breaths/min) & $20(20 \sim 23.75)$ \\
\hline & Systolic pressure (mmHg) & $122\left(115^{\sim 134.8)}\right.$ \\
\hline & Diastolic pressure (mmHg) & $75(75 \sim 85)$ \\
\hline \multicolumn{3}{|c|}{ Complications on admission } \\
\hline & Respiratory failure & $20(10.6 \%)$ \\
\hline & ARDS or sepsis & $6(3.2 \%)$ \\
\hline \multirow[t]{3}{*}{ hs-Tnl (pg/mL) } & Median $\left(25^{\text {th }}\right.$ and $75^{\text {th }}$ percentile $)$ & $3.65(1.3 \sim 9.425)$ \\
\hline & $33^{\text {th }}$ and $67^{\text {th }}$ percentile & $2 \sim 6.126$ \\
\hline & $>28 \mathrm{pg} / \mathrm{mL}$ ( clinical upper normal limit) & $21(11.2 \%)$ \\
\hline \multirow[t]{3}{*}{$\mathrm{LDH}(\mathrm{U} / \mathrm{L})$} & Median $\left(25^{\text {th }}\right.$ and $75^{\text {th }}$ percentile $)$ & $308.5\left(233.3^{\sim} 389.8\right)$ \\
\hline & $33^{\text {th }}$ and $67^{\text {th }}$ percentile & $253.2 \sim 354.5$ \\
\hline & $>250 \mathrm{U} / \mathrm{L}$ (clinical upper normal limit) & $129(68.6 \%)$ \\
\hline \multirow{3}{*}{$\begin{array}{l}\alpha-H B D H(n=173) \\
(U / L)\end{array}$} & Median $\left(25^{\text {th }}\right.$ and $75^{\text {th }}$ percentile $)$ & $255\left(198.5^{\sim 337)}\right.$ \\
\hline & $33^{\text {th }}$ and $67^{\text {th }}$ percentile & $215.8 \sim 305$ \\
\hline & > 182 U/L (clinical upper normal limit) & $143(76.1 \%)$ \\
\hline
\end{tabular}


medRxiv preprint doi: https://doi.org/10.1101/2020.02.26.20028589; this version posted February 29, 2020. The copyright holder for this preprint (which was not certified by peer review) is the author/funder, who has granted medRxiv a license to display the preprint in perpetuity. All rights reserved. No reuse allowed without permission.

\begin{tabular}{|l|l|c|}
\hline CK (U/L) & Median $\left(25^{\text {th }}\right.$ and $75^{\text {th }}$ percentile) & $83\left(46.25^{\sim 159.5}\right)$ \\
\hline & $33^{\text {th }}$ and $67^{\text {th }}$ percentile & $53.74 \sim 123.6$ \\
\hline & $>310 \mathrm{U} / \mathrm{L}$ (clinical upper normal limit) & $21(11.2 \%)$ \\
\hline CK-MB (U/L) & Median $\left(25^{\text {th }}\right.$ and $75^{\text {th }}$ percentile) & $15\left(12^{\sim} 20\right)$ \\
\hline & $33^{\text {th }}$ and $67^{\text {th }}$ percentile & $13 \sim 18$ \\
\hline Drug therapy & $>24 \mathrm{U} / \mathrm{L}$ ( clinical upper normal limit) & $19(10.1 \%)$ \\
\hline & & $185(98.4 \%)$ \\
\hline & Antibiotics & $158(84.0 \%)$ \\
\hline Aransfer to ICU & Antiviral drugs & $59(31.4 \%)$ \\
\hline Cured or deceased & & $50(26.6 \%)$ \\
\hline & Cured and discharged & $145(77.1 \%)$ \\
\hline & Length of stay (days) for cured patients & $12(9-14)$ \\
\hline & Deceased in hospital & $43(22.9 \%)$ \\
\hline & Length of stay (days) for deceased patients & $7(4-11)$ \\
\hline & (survival days) & \\
\hline
\end{tabular}

a Besides hypertension and diabetes, other comorbidity included chronic liver disease ( 9 cases), coronary heart disease (6 cases), cerebrovascular disease (6 cases), Parkinson's disease (3 cases), rheumatoid disease (3 cases), chronic kidney disease ( 3 cases), thyroid disease ( 2 cases), stomach disease ( 3 cases), chronic obstructive pulmonary disease ( 2 cases) and pulmonary tuberculosis ( 3 cases).

${ }^{\mathrm{b}}$ Other symptoms and signs included headache (12 cases), nasal obstruction or nasal discharge (8 cases), nausea and vomiting ( 7 cases), dizziness ( 6 cases), pharyngalgia (6 cases) and diarrhea ( 2 cases).

Continuous data were presented by mean \pm standard deviation (SD), median $\left(25^{\text {th }}\right.$ to $75^{\text {th }}$ percentile) or $33^{\text {th }}$ to $67^{\text {th }}$ percentile.

Categorical data were presented by number with percentage.

Abbreviations: ARDS: acute respiratory distress syndrome; hsTnl: High-sensitivity troponin I; LDH: Lactic dehydrogenase; $\alpha$-HBDH: $\alpha$-hydroxybutyrate dehydrogenase; CK: Creatine kinase; CK-MB: creatine kinase-MB; ICU: intensive care unit. 
medRxiv preprint doi: https://doi.org/10.1101/2020.02.26.20028589; this version posted February 29, 2020. The copyright holder for this preprint (which was not certified by peer review) is the author/funder, who has granted medRxiv a license to display the preprint in perpetuity.

All rights reserved. No reuse allowed without permission.

Table 2, Clinical characteristics and outcomes between patients with different hs-Tnl levels.

\begin{tabular}{|c|c|c|c|}
\hline Parameters & Low hs-Tnl group & Moderate hs-Tnl group & High hs-Tnl group \\
\hline Age (years) & $43.57 \pm 11.99$ & $50.76 \pm 11.11^{\#}$ & $61.19 \pm 13.98 * \S$ \\
\hline Male & $56.7 \%(34 / 60)$ & $69.7 \%(46 / 66)$ & $62.9 \%(39 / 62)$ \\
\hline Current smoking & $10.0 \%(6 / 60)$ & $10.6 \%(7 / 66)$ & $6.5 \%(4 / 62)$ \\
\hline Comorbidity & $23.3 \%(14 / 60)$ & $27.3 \%(18 / 66)$ & $51.6 \%(32 / 62) * \S$ \\
\hline Hypertension & $11.7 \%(7 / 60)$ & $15.2 \%(10 / 66)$ & $33.9 \%(21 / 62) * \S$ \\
\hline Diabetes & $3.3 \%(2 / 60)$ & $7.6 \%(5 / 66)$ & $21.0 \%(13 / 62) \S$ \\
\hline \multicolumn{4}{|l|}{ Initial symptoms and signs } \\
\hline Fever & $95.0 \%(57 / 60)$ & $93.9 \%(62 / 66)$ & $88.7 \%(55 / 62)$ \\
\hline Highest temperature $\left({ }^{\circ} \mathrm{C}\right)$ & $38.77 \pm 0.71$ & $38.66 \pm 0.56$ & $38.78 \pm 0.75$ \\
\hline Breathlessness & $30.0 \%(18 / 60)$ & $37.9 \%(25 / 66)$ & $46.8 \%(29 / 62)$ \\
\hline Chest distress or pain & $33.3 \%(20 / 60)$ & $28.8 \%(19 / 66)$ & $38.7 \%(24 / 62)$ \\
\hline Fatigue or myalgia & $30.0 \%(18 / 60)$ & $36.4 \%(24 / 66)$ & $30.6 \%(19 / 62)$ \\
\hline Dyspnea & $10.0 \%(6 / 60)$ & $12.1 \%(8 / 66)$ & $16.1 \%(10 / 62)$ \\
\hline Respiratory failure, ARDS or sepsis & $13.3 \%(8 / 60)$ & $10.6 \%(7 / 66)$ & $17.7 \%(11 / 62)$ \\
\hline \multicolumn{4}{|l|}{ Vital signs on admission } \\
\hline Heart rate (beats/min) & $85.5(80.5 \sim 94)$ & 87 (82 98) & $89.5(82 \sim 98)$ \\
\hline Systolic pressure (mmHg) & $119\left(112^{\sim} 130.3\right)$ & $119.5\left(115^{\sim} 129.5\right)$ & $130\left(118.3^{\sim} 143\right)^{\S}$ \\
\hline Diastolic pressure $(\mathrm{mmHg})$ & $76(72.75 \sim 85)$ & $75\left(75^{\sim} 83\right)$ & 77 (72 87) \\
\hline \multicolumn{4}{|l|}{ Inflammatory and immune indexes } \\
\hline WBC $\left(\times 10^{\wedge} 9 / \mathrm{L}\right)$ & $6.04(4.21 \sim 9.60)$ & $5.77(3.84 \sim 8.65)$ & $5.72(3.73 \sim 9.25)$ \\
\hline Neutrophil percentage (\%) & $73.4(61.28 \sim 84.7)$ & $75.2(57.8 \sim 83.88)$ & $80.55(70 \sim 89.93)$ * \\
\hline Lymphocytes percentage (\%) & $18.6\left(9.3^{\sim} 31.85\right)$ & $16.5(9.3 \sim 32.53)$ & $12.95(5.68 \sim 23.2) * \S$ \\
\hline Monocytes percentage (\%) & $5.7\left(4.2^{\sim 7.4)}\right.$ & $6.3(4.78 \sim 8.13)$ & $4.75(3.15 \sim 6.58) *$ \\
\hline $\mathrm{IL}-6(\mathrm{pg} / \mathrm{mL})$ & $6.02\left(5.21^{\sim 7.82}\right)$ & $6.2\left(5.20^{\sim} 7.48\right)$ & $8.92\left(6.9^{\sim} 13.4\right) * \S$ \\
\hline CRP (mg/L) & $22.6(6.5 \sim 46.15)$ & $37.2(11.3 \sim 80.5)$ & $55.3\left(25.65^{\sim} 108.2\right)^{\S}$ \\
\hline $\mathrm{PCT} \geq 0.05 \mathrm{ng} / \mathrm{mL}$ & $31.7 \%(19 / 60)$ & $36.4 \%(24 / 66)$ & $64.5 \%(40 / 62) * \S$ \\
\hline $\mathrm{ESR}(\mathrm{mm} / \mathrm{h})$ & $49(39.75 \sim 65.25)$ & $49(42.18 \sim 69)$ & $56.3(39.5 \sim 68.15)$ \\
\hline T cells count $(/ \mathrm{uL})$ & 737 (544 1156) & $628(468 \sim 846)$ & $575\left(347.8^{\sim} 782.8\right)^{\S}$ \\
\hline $\mathrm{CD}^{+} \mathrm{T}$ cells count $(/ \mathrm{uL})$ & $428\left(291.5^{\sim 750.5)}\right.$ & $362(283 \sim 572)$ & $337.5(166.3 \sim 452.3)^{\S}$ \\
\hline $\mathrm{CD}^{+} \mathrm{T}$ cells count $(/ \mathrm{uL})$ & $311\left(162.5^{\sim} 421.5\right)$ & $236(163 \sim 349)$ & $231.5\left(123^{\sim} 290.5\right)^{\S}$ \\
\hline \multicolumn{4}{|l|}{ Outcomes } \\
\hline Transfer to ICU & $15.0 \%(9 / 60)$ & $21.2 \%(14 / 66)$ & $43.5 \%(27 / 62) * \S$ \\
\hline Mortality & $10.0 \%(6 / 60)$ & $9.1 \%(6 / 66)$ & $50 \%(31 / 62) * \S$ \\
\hline Days from admission to death & $11(4.75 \sim 11.75)$ & $8.5\left(5.75^{\sim 14.25)}\right.$ & $7\left(4^{\sim 11}\right)$ \\
\hline
\end{tabular}

Low hs-Tnl group ( $\mathrm{n=60):} \mathrm{hs-Tnl}<2 \mathrm{pg} / \mathrm{mL}$; Moderate hs-Tnl group ( $\mathrm{n=66):} 2 \leq \mathrm{hs}-\mathrm{Tnl}<6.126 \mathrm{pg} / \mathrm{mL}$; High hs-Tnl group (n=62): hs-Tnl $\geq 6.126 \mathrm{pg} / \mathrm{mL}$.

${ }^{\#}$ Statistically significant for Moderate hs-Tnl group vs. Low hs-Tnl group $(P<0.05)$.

* Statistically significant for High hs-Tnl group vs. Moderate hs-Tnl group $(\mathrm{P}<0.05)$. 
medRxiv preprint doi: https://doi.org/10.1101/2020.02.26.20028589; this version posted February 29, 2020. The copyright holder for this preprint (which was not certified by peer review) is the author/funder, who has granted medRxiv a license to display the preprint in perpetuity.

All rights reserved. No reuse allowed without permission.

${ }^{\S}$ Statistically significant for High hs-Tnl group vs. Low hs-Tnl group $(P<0.05)$.

Continuous data were presented by mean \pm standard deviation (SD) or median $\left(25^{\text {th }}\right.$ to $75^{\text {th }}$ percentile). Categorical data were presented by percentage with number.

Abbreviations: hsTnl: High-sensitivity troponin I; ARDS: acute respiratory distress syndrome; WBC: white blood cells; IL-6: interleukin-6; CRP: C-reaction protein; PCT: procalcitonin; ESR: erythrocyte sedimentation rate; ICU: intensive care unit. 
medRxiv preprint doi: https://doi.org/10.1101/2020.02.26.20028589; this version posted February 29, 2020. The copyright holder for this preprint (which was not certified by peer review) is the author/funder, who has granted medRxiv a license to display the preprint in perpetuity.

All rights reserved. No reuse allowed without permission.

Table 3, Clinical characteristics and outcomes between patients with different CK-MB levels.

\begin{tabular}{|c|c|c|c|}
\hline Parameters & Low CK-MB group & Moderate CK-MB group & High CK-MB group \\
\hline Age (years) & $50.15 \pm 13.54$ & $51.19 \pm 13.33$ & $54.11 \pm 15.77$ \\
\hline Male & $41.7 \%(20 / 48)$ & $67.5 \%(52 / 77)^{\#}$ & $74.6 \%(47 / 63)^{\S}$ \\
\hline Current smoking & $0.0 \%(0 / 48)$ & $9.1 \%(7 / 77)$ & $15.9 \%(10 / 63)^{\S}$ \\
\hline Comorbidity & $29.2 \%(14 / 48)$ & $31.2 \%(24 / 77)$ & $41.3 \%(26 / 63)$ \\
\hline Hypertension & $12.5 \%(6 / 48)$ & $18.2 \%(14 / 77)$ & $28.6 \%(18 / 63)$ \\
\hline Diabetes & $4.2 \%(2 / 48)$ & $10.4 \%(8 / 77)$ & $15.9 \%(10 / 63)$ \\
\hline \multicolumn{4}{|l|}{ Initial symptoms and signs } \\
\hline Fever & $85.4 \%(41 / 48)$ & $93.5 \%(72 / 77)$ & $96.8 \%(61 / 63)$ \\
\hline Highest temperature $\left({ }^{\circ} \mathrm{C}\right)$ & $38.61 \pm 0.79$ & $38.71 \pm 0.56$ & $38.85 \pm 0.71$ \\
\hline Breathlessness & $33.3 \%(16 / 48)$ & $32.5 \%(25 / 77)$ & $49.2 \%(31 / 63)$ \\
\hline Chest distress or pain & $33.3 \%(16 / 48)$ & $29.9 \%(23 / 77)$ & $38.1 \%(24 / 63)$ \\
\hline Fatigue or myalgia & $29.2 \%(14 / 48)$ & $33.8 \%(26 / 77)$ & $33.3 \%(21 / 63)$ \\
\hline Dyspnea & $10.4 \%(5 / 48)$ & $13.0 \%(10 / 77)$ & $14.3 \%(9 / 63)$ \\
\hline Respiratory failure, ARDS or sepsis & $12.5 \%(6 / 48)$ & $15.6 \%(12 / 77)$ & $12.7 \%(8 / 63)$ \\
\hline \multicolumn{4}{|l|}{ Vital signs on admission } \\
\hline Heart rate (beats/min) & $87\left(82^{\sim 97}\right)$ & $88\left(82^{\sim 98}\right)$ & $86\left(82^{\sim 96}\right)$ \\
\hline Systolic pressure (mmHg) & $119.5\left(108.5^{\sim} 131\right)$ & $119\left(116^{\sim 133)}\right.$ & $123\left(115^{\sim} 140\right)$ \\
\hline Diastolic pressure $(\mathrm{mmHg})$ & 75 (72 87) & $75\left(75^{\sim} 83.5\right)$ & 75 (75 87) \\
\hline \multicolumn{4}{|l|}{ Inflammatory and immune indexes } \\
\hline WBC $\left(\times 10^{\wedge} 9 / L\right)$ & $5.25(3.58 \sim 6.72)$ & $5.92(3.74 \sim 8.5)$ & $7.83\left(4.45^{\sim} 10.76\right)^{\S}$ \\
\hline Neutrophil percentage (\%) & $70.8(59.03 \sim 82.6)$ & $74.7(60.6 \sim 85.8)$ & $82(68.7 \sim 89.6) * \S$ \\
\hline Lymphocytes percentage (\%) & $21\left(10.75^{\sim} 30.38\right)$ & $16.8\left(9.3^{\sim} 32.15\right)$ & $11(6.4 \sim 23.2) * \S$ \\
\hline Monocytes percentage (\%) & $5.95\left(4.53^{\sim 7.35}\right)$ & $5.7\left(4.2^{\sim 7.4)}\right.$ & $4.9\left(3.2^{\sim 7.4)}\right.$ \\
\hline IL-6 (pg/mL) & $6.76(5.34 \sim 10.75)$ & 7.36 (5.39 8.93) & $7.4\left(5.5^{\sim} 10.42\right)$ \\
\hline $\mathrm{CRP}(\mathrm{mg} / \mathrm{L})$ & $26.15(5.15 \sim 69.18)$ & $34.95\left(10.1^{\sim 76.18}\right)$ & $51.7\left(24.6^{\sim} 90.8\right)^{\S}$ \\
\hline $\mathrm{PCT} \geq 0.05 \mathrm{ng} / \mathrm{mL}$ & $31.3 \%(15 / 48)$ & $42.9 \%(33 / 77)$ & $55.6 \%(35 / 63)^{\S}$ \\
\hline $\operatorname{ESR}(\mathrm{mm} / \mathrm{h})$ & $52.7(41.93 \sim 65)$ & 49 (39 70) & $49(37.8 \sim 66)$ \\
\hline T cells count $(/ \mathrm{uL})$ & $660\left(547^{\sim 975)}\right.$ & $628(453 \sim 959)$ & $587.5(366.5 \sim 846)$ \\
\hline $\mathrm{CD} 4^{+} \mathrm{T}$ cells count $(/ \mathrm{uL})$ & $390(345 \sim 578)$ & $382(270 \sim 652)$ & $291.5(194 \sim 523)$ \\
\hline $\mathrm{CD}^{+} \mathrm{T}$ cells count $(/ \mathrm{uL})$ & 239 (171 323) & $277(154 \sim 355)$ & $231\left(134.5^{\sim} 353.5\right)$ \\
\hline \multicolumn{4}{|l|}{ Outcomes } \\
\hline Transfer to ICU & $18.8 \%(9 / 48)$ & $18.2 \%(14 / 77)$ & $42.9 \%(27 / 63) * \S$ \\
\hline Mortality & $18.8 \%(9 / 48)$ & $15.6 \%(12 / 77)$ & $34.9 \%(22 / 63) *$ \\
\hline Days from admission to death & $7\left(5^{\sim} 15.5\right)$ & $11(3.25 \sim 13.75)$ & $7(4 \sim 8.5)$ \\
\hline
\end{tabular}

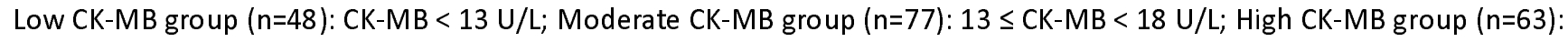
CK-MB $\geq 18 \mathrm{U} / \mathrm{L}$.

${ }^{\#}$ Statistically significant for Moderate CK-MB group vs. Low CK-MB group $(\mathrm{P}<0.05)$.

* Statistically significant for High CK-MB group vs. Moderate CK-MB group $(\mathrm{P}<0.05)$. 
medRxiv preprint doi: https://doi.org/10.1101/2020.02.26.20028589; this version posted February 29, 2020. The copyright holder for this preprint (which was not certified by peer review) is the author/funder, who has granted medRxiv a license to display the preprint in perpetuity. All rights reserved. No reuse allowed without permission.

${ }^{\S}$ Statistically significant for High CK-MB group vs. Low CK-MB group $(P<0.05)$.

Continuous data were presented by mean \pm standard deviation (SD) or median $\left(25^{\text {th }}\right.$ to $75^{\text {th }}$ percentile). Categorical data were presented by percentage with number.

Abbreviations: CK-MB: creatine kinase-MB; ARDS: acute respiratory distress syndrome; WBC: white blood cells; IL-6: interleukin-6; CRP: C-reaction protein; PCT: procalcitonin; ESR: erythrocyte sedimentation rate; ICU: intensive care unit. 
medRxiv preprint doi: https://doi.org/10.1101/2020.02.26.20028589; this version posted February 29, 2020. The copyright holder for this preprint (which was not certified by peer review) is the author/funder, who has granted medRxiv a license to display the preprint in perpetuity.

All rights reserved. No reuse allowed without permission.

Table 4, Clinical characteristics and outcomes between patients with different LDH levels.

\begin{tabular}{|c|c|c|c|}
\hline Parameters & Low LDH group & Moderate LDH group & High LDH group \\
\hline Age (years) & $46.97 \pm 11.2$ & $50.22 \pm 13.54$ & $58.58 \pm 15.35 * \S$ \\
\hline Male & $51.6 \%(32 / 62)$ & $67.2 \%(43 / 64)$ & $71.0 \%(44 / 62)$ \\
\hline Current smoking & $8.1 \%(5 / 62)$ & $7.8 \%(5 / 64)$ & $11.3 \%(7 / 62)$ \\
\hline Comorbidity & $27.4 \%(17 / 62)$ & $31.3 \%(20 / 64)$ & $43.5 \%(27 / 62)$ \\
\hline Hypertension & $9.7 \%(6 / 62)$ & $18.8 \%(12 / 64)$ & $32.3 \%(20 / 62)^{\S}$ \\
\hline Diabetes & $4.8 \%(3 / 62)$ & $9.4 \%(6 / 64)$ & $17.7 \%(11 / 62)$ \\
\hline \multicolumn{4}{|l|}{ Initial symptoms and signs } \\
\hline Fever & $91.9 \%(57 / 62)$ & $92.2 \%(59 / 64)$ & $93.5 \%(58 / 62)$ \\
\hline Highest temperature $\left({ }^{\circ} \mathrm{C}\right)$ & $38.53 \pm 0.69$ & $38.76 \pm 0.58$ & $38.9 \pm 0.70$ \\
\hline Breathlessness & $22.6 \%(14 / 62)$ & $29.7 \%(19 / 64)$ & $62.9 \%(39 / 62) * \S$ \\
\hline Chest distress or pain & $17.7 \%(11 / 62)$ & $28.1 \%(18 / 64)$ & $54.8 \%(34 / 62) * \S$ \\
\hline Fatigue or myalgia & $30.6 \%(19 / 62)$ & $34.4 \%(22 / 64)$ & $32.3 \%(20 / 62)$ \\
\hline Dyspnea & $4.8 \%(3 / 62)$ & $12.5 \%(8 / 64)$ & $21.0 \%(13 / 62)^{\S}$ \\
\hline Respiratory failure, ARDS or sepsis & $4.8 \%(3 / 62)$ & $12.5 \%(8 / 64)$ & $24.2 \%(15 / 62)^{\S}$ \\
\hline \multicolumn{4}{|l|}{ Vital signs on admission } \\
\hline Heart rate (beats/min) & $87.5\left(82^{\sim 98}\right)$ & $88(82 \sim 96.75)$ & $87(82 \sim 98)$ \\
\hline Systolic pressure (mmHg) & $119\left(115^{\sim} 127.3\right)$ & $119\left(112.5^{\sim} 129\right)$ & $132.5(119 \sim 144.3) * \S$ \\
\hline Diastolic pressure $(\mathrm{mmHg})$ & $75\left(75^{\sim} 85.5\right)$ & $76\left(75^{\sim} 84\right)$ & 77 (72 87) \\
\hline \multicolumn{4}{|l|}{ Inflammatory and immune indexes } \\
\hline WBC $\left(\times 10^{\wedge} 9 / \mathrm{L}\right)$ & $4.81\left(3.37^{\sim} 6.91\right)$ & $5.81(3.59 \sim 8.27)$ & $8.07(5.12 \sim 11.02) * \S$ \\
\hline Neutrophil percentage (\%) & $63.25\left(54.65^{\sim 76.03)}\right.$ & $79.4(68.33 \sim 83.75)^{\#}$ & $87.25(74.03 \sim 91.88) * \S$ \\
\hline Lymphocytes percentage (\%) & $27.8(17.25 \sim 35.43)$ & $14.95\left(10.63^{\sim 23.35)^{\#}}\right.$ & $8.6(5.28 \sim 17.95) * \S$ \\
\hline Monocytes percentage (\%) & $6.85(5.58 \sim 8.4)$ & $5.65(4.65 \sim 7.1)$ & $3.55(2.38 \sim 5.55) * \S$ \\
\hline IL-6 (pg/mL) & $5.46(4.94 \sim 7.66)$ & $6.53\left(5.52^{\sim 7.47)}\right.$ & $8.63(6.32 \sim 12.88) * \S$ \\
\hline $\mathrm{CRP}(\mathrm{mg} / \mathrm{L})$ & $8.45\left(2.8^{\sim} 28.45\right)$ & $46\left(22.5^{\sim} 97.2\right)^{\#}$ & $64.7\left(34.6^{\sim} 107.8\right)^{\S}$ \\
\hline $\mathrm{PCT} \geq 0.05 \mathrm{ng} / \mathrm{mL}$ & $17.7 \%(11 / 62)$ & $46.9 \%(30 / 64)^{\#}$ & $67.7 \%(42 / 62)^{\S}$ \\
\hline $\mathrm{ESR}(\mathrm{mm} / \mathrm{h})$ & $45(35.85 \sim 62.5)$ & $48(36.3 \sim 65)$ & $61\left(43^{\sim} 70.5\right)^{\S}$ \\
\hline T cells count $(/ \mathrm{uL})$ & $703\left(525^{\sim} 1030\right)$ & $633(467 \sim 882)$ & $458.5\left(353.8^{\sim} 728.3\right)^{\S}$ \\
\hline $\mathrm{CD}^{+} \mathrm{T}$ cells count $(/ \mathrm{uL})$ & $428(334 \sim 736)$ & $342(261 \sim 501)$ & $287.5(148.8 \sim 442)^{\S}$ \\
\hline $\mathrm{CD}^{+} \mathrm{T}$ cells count $(/ \mathrm{uL})$ & $236\left(169.5^{\sim} 376.5\right)$ & $278\left(157^{\sim} 368\right)$ & $184.5\left(98.5^{\sim} 295\right)$ \\
\hline \multicolumn{4}{|l|}{ Outcomes } \\
\hline Transfer to ICU & $6.5 \%(4 / 62)$ & $17.2 \%(11 / 64)$ & $56.5 \%(35 / 62) * \S$ \\
\hline Mortality & $3.2 \%(2 / 62)$ & $12.5 \%(8 / 64)$ & $53.2 \%(33 / 62) * \S$ \\
\hline Days from admission to death & $11\left(11^{\sim} 11\right)$ & $11(4.5 \sim 21.5)$ & $7\left(4^{\sim} 10\right)$ \\
\hline
\end{tabular}

Low LDH group ( $n=62$ ): LDH < 253.2 U/L; Moderate LDH group ( $n=64): 253.2 \leq \mathrm{LDH}<354.5 \mathrm{U} / \mathrm{L}$; High LDH group ( $\mathrm{n=62}$ ): $\mathrm{LDH} \geq 354.5 \mathrm{U} / \mathrm{L}$.

"Statistically significant for Moderate LDH group vs. Low LDH group $(\mathrm{P}<0.05)$. 
medRxiv preprint doi: https://doi.org/10.1101/2020.02.26.20028589; this version posted February 29, 2020. The copyright holder for this preprint (which was not certified by peer review) is the author/funder, who has granted medRxiv a license to display the preprint in perpetuity.

All rights reserved. No reuse allowed without permission.

* Statistically significant for High LDH group vs. Moderate LDH group $(\mathrm{P}<0.05)$.

${ }^{\S}$ Statistically significant for High LDH group vs. Low LDH group $(P<0.05)$.

Continuous data were presented by mean \pm standard deviation $(S D)$ or median $\left(25^{\text {th }}\right.$ to $75^{\text {th }}$ percentile). Categorical data were presented by percentage with number.

Abbreviations: LDH: lactic dehydrogenase; ARDS: acute respiratory distress syndrome; WBC: white blood cells; IL-6: interleukin-6; CRP: C-reaction protein; PCT: procalcitonin; ESR: erythrocyte sedimentation rate; ICU: intensive care unit. 
medRxiv preprint doi: https://doi.org/10.1101/2020.02.26.20028589; this version posted February 29, 2020. The copyright holder for this preprint (which was not certified by peer review) is the author/funder, who has granted medRxiv a license to display the preprint in perpetuity.

All rights reserved. No reuse allowed without permission.

Table 5, Clinical characteristics and outcomes between patients with different $\alpha$-HBDH levels.

\begin{tabular}{|c|c|c|c|}
\hline Parameters & Low $\alpha-H B D H$ group & Moderate $\alpha$-HBDH group & High $\alpha-H B D H$ group \\
\hline Age (years) & $46.98 \pm 11.28$ & $50.28 \pm 15.47$ & $59.22 \pm 13.85 * \S$ \\
\hline Male & $54.4 \%(31 / 57)$ & $62.1 \%(36 / 58)$ & $74.1 \%(43 / 58)$ \\
\hline Current smoking & $5.3 \%(3 / 57)$ & $10.3 \%(6 / 58)$ & $8.6 \%(5 / 58)$ \\
\hline Comorbidity & $24.6 \%(14 / 57)$ & $34.5 \%(20 / 58)$ & $46.6 \%(27 / 58)^{\S}$ \\
\hline Hypertension & $7.0 \%(4 / 57)$ & $24.1 \%(14 / 58)^{\#}$ & $32.8 \%(19 / 58)^{\S}$ \\
\hline Diabetes & $3.5 \%(2 / 57)$ & $10.3 \%(6 / 58)$ & $17.2 \%(10 / 58)$ \\
\hline \multicolumn{4}{|l|}{ Initial symptoms and signs } \\
\hline Fever & $91.2 \%(52 / 57)$ & $93.1 \%(54 / 58)$ & $94.8 \%(55 / 58)$ \\
\hline Highest temperature $\left({ }^{\circ} \mathrm{C}\right)$ & $38.63 \pm 0.67$ & $38.68 \pm 0.67$ & $38.93 \pm 0.68$ \\
\hline Breathlessness & $26.3 \%(15 / 57)$ & $22.4 \%(13 / 58)$ & $63.8 \%(37 / 58) * \S$ \\
\hline Chest distress or pain & $17.5 \%(10 / 57)$ & $27.6 \%(16 / 58)$ & $55.2 \%(32 / 58) * \S$ \\
\hline Fatigue or myalgia & $21.1 \%(12 / 57)$ & $37.9 \%(22 / 58)$ & $32.8 \%(19 / 58)$ \\
\hline Dyspnea & $5.3 \%(3 / 57)$ & $12.1 \%(7 / 58)$ & $22.4 \%(13 / 58)^{\S}$ \\
\hline Respiratory failure, ARDS or sepsis & $5.3 \%(3 / 57)$ & $10.3 \%(6 / 58)$ & $20.7 \%(12 / 58)^{\S}$ \\
\hline \multicolumn{4}{|l|}{ Vital signs on admission } \\
\hline Heart rate (beats/min) & $87\left(81.5^{\sim 98}\right)$ & $88\left(82^{\sim 9} \sim 9\right)$ & $88(82 \sim 98)$ \\
\hline Systolic pressure (mmHg) & $119\left(113.5^{\sim} 125.5\right)$ & $119(115 \sim 129.5)$ & $131.5(119 \sim 143) * \S$ \\
\hline Diastolic pressure (mmHg) & $75\left(73.5^{\sim} 84.5\right)$ & $75\left(75^{\sim} 83\right)$ & $77(73.5 \sim 87)$ \\
\hline \multicolumn{4}{|l|}{ Inflammatory and immune indexes } \\
\hline WBC $\left(\times 10^{\wedge} 9 / L\right)$ & $4.84(3.42 \sim 6.27)$ & $5.95(3.73 \sim 8.79)$ & $7.90\left(4.50^{\sim} 10.32\right)^{\S}$ \\
\hline Neutrophil percentage (\%) & $66.6\left(55.85^{\sim 76.05)}\right.$ & $78.95\left(64.73^{\sim} 85.03\right)^{\#}$ & $85.8(70.55 \sim 90.53) * \S$ \\
\hline Lymphocytes percentage (\%) & $27.5\left(15.7^{\sim 35.2}\right)$ & $15.05\left(8.63^{\sim} 26.2\right)^{\#}$ & $9.15\left(5.55^{\sim} 22.35\right)^{\S}$ \\
\hline Monocytes percentage (\%) & $6.8(5.5 \sim 8.3)$ & $5.7(4.68 \sim 7.75)$ & $3.8(2.53 \sim 5.88) * \S$ \\
\hline IL-6 (pg/mL) & $5.67(5.29 \sim 7.88)$ & $6.06\left(5.30^{\sim 7.42}\right)$ & $8.83(7.32 \sim 13.44) * \S$ \\
\hline $\mathrm{CRP}(\mathrm{mg} / \mathrm{L})$ & $8.2\left(3.05^{\sim} 41.35\right)$ & $33.1\left(16.1^{\sim 71.15)^{\#}}\right.$ & $67.9(37.5 \sim 112.2) * \S$ \\
\hline $\mathrm{PCT} \geq 0.05 \mathrm{ng} / \mathrm{mL}$ & $28.1 \%(16 / 57)$ & $37.9 \%(22 / 58)$ & $69.0 \%(40 / 58)^{\S}$ \\
\hline $\mathrm{ESR}(\mathrm{mm} / \mathrm{h})$ & $44\left(30.6^{\sim} 63.5\right)$ & $52\left(41.8^{\sim} 71\right)$ & $57.15(41.9 \sim 68.48)$ \\
\hline T cells count $(/ \mathrm{uL})$ & $771(563 \sim 1030)$ & $620(385.3 \sim 823.5)^{\#}$ & $470.5\left(366.5^{\sim 993.5}\right)^{\S}$ \\
\hline $\mathrm{CD}^{+} \mathrm{T}$ cells count $(/ \mathrm{uL})$ & $434.5\left(355.3^{\sim 743.8)}\right.$ & $328(218 \sim 490.8)^{\#}$ & $286.5\left(164.5^{\sim} 487\right)^{\S}$ \\
\hline $\mathrm{CD}^{+} \mathrm{T}$ cells count $(/ \mathrm{uL})$ & $255.5(196.3 \sim 421.3)$ & $234.5(154 \sim 357.3)$ & $230(118.8 \sim 325.8)$ \\
\hline \multicolumn{4}{|l|}{ Outcomes } \\
\hline Transfer to ICU & $1.8 \%(1 / 57)$ & $17.2 \%(10 / 58)^{\#}$ & $48.3 \%(28 / 58) * \S$ \\
\hline Mortality & $3.5 \%(2 / 57)$ & $15.5 \%(9 / 58)$ & $53.4 \%(31 / 58) * \S$ \\
\hline Days from admission to death & $8.5\left(6^{\sim 11}\right)$ & 11 (4 19) & $7(4 \sim 10)$ \\
\hline
\end{tabular}

Low $\alpha$-HBDH group ( $n=57$ ): $\alpha$-HBDH <215.8 U/L; Moderate $\alpha$-HBDH group ( $n=58): 215.8 \leq \alpha-H B D H<305 \mathrm{U} / \mathrm{L}$; High $\alpha$-HBDH group ( $\mathrm{n}=58$ ): $\alpha-\mathrm{HBDH} \geq 305 \mathrm{U} / \mathrm{L}$.

${ }^{\#}$ Statistically significant for Moderate $\alpha-\mathrm{HBDH}$ group vs. Low $\alpha-\mathrm{HBDH}$ group $(\mathrm{P}<0.05)$. 
medRxiv preprint doi: https://doi.org/10.1101/2020.02.26.20028589; this version posted February 29, 2020. The copyright holder for this preprint (which was not certified by peer review) is the author/funder, who has granted medRxiv a license to display the preprint in perpetuity.

All rights reserved. No reuse allowed without permission.

* Statistically significant for High $\alpha-\mathrm{HBDH}$ group vs. Moderate $\alpha-\mathrm{HBDH}$ group $(\mathrm{P}<0.05)$.

${ }^{\S}$ Statistically significant for High $\alpha-\mathrm{HBDH}$ group vs. Low $\alpha-\mathrm{HBDH}$ group $(\mathrm{P}<0.05)$.

Continuous data were presented by mean \pm standard deviation $(S D)$ or median $\left(25^{\text {th }}\right.$ to $75^{\text {th }}$ percentile). Categorical data were presented by percentage with number.

Abbreviations: $\alpha$-HBDH: $\alpha$-hydroxybutyrate dehydrogenase; ARDS: acute respiratory distress syndrome; WBC: white blood cells; IL-6: interleukin-6; CRP: C-reaction protein; PCT: procalcitonin; ESR: erythrocyte sedimentation rate; ICU: intensive care unit. 

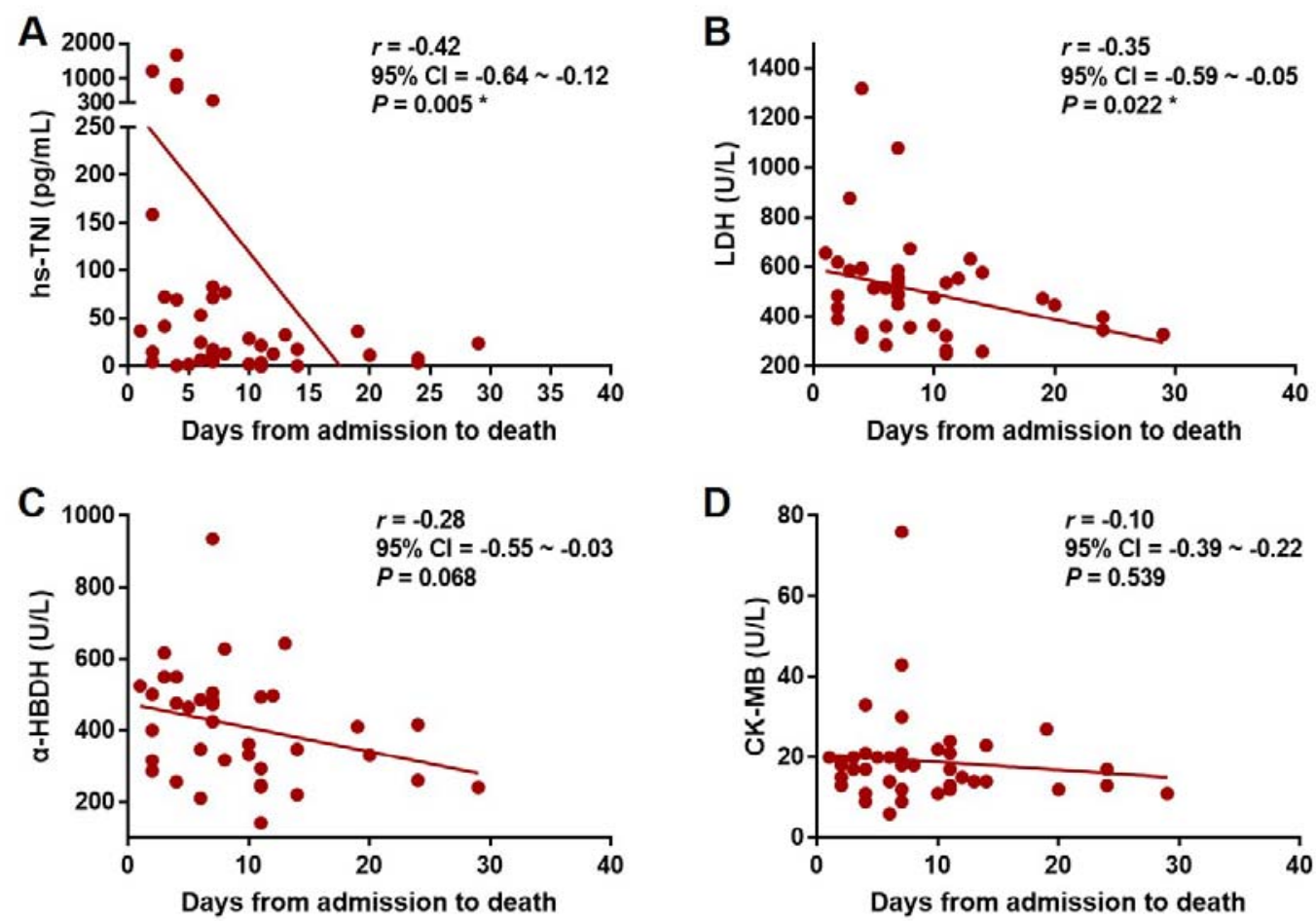

Figure 1, Correlations of heart injury indicators with survival days for deceased patients. A: Correlation of hs-TNI with survival days; B: Correlation of LDH with survival days; C: Correlation of $\alpha$-HBDH with survival days; D: Correlation of CK-MB with survival days.

* Statistically significant. 
medRxiv preprint doi: https://doi.org/10.1101/2020.02.26.20028589; this version posted February 29, 2020. The copyright holder for this preprint (which was not certified by peer review) is the author/funder, who has granted medRxiv a license to display the preprint in perpetuity. All rights reserved. No reuse allowed without permission.

\section{Supplementary material}

Supplementary table 1, Mortality between patients with different CK levels.

\begin{tabular}{|l|c|c|c|c|}
\hline & Low CK group & Moderate CK group & High CK group & $\mathrm{P}$ \\
\hline Mortality & $17.7 \%(11 / 62)$ & $32.8 \%(21 / 64)$ & $17.7 \%(11 / 62)$ & 0.066 \\
\hline
\end{tabular}

CK: Creatine kinase. 